\title{
IDENTIFIKASI KEMAMPUAN BERPIKIR KREATIF MATEMATIS SISWA PADA MATERI PERSAMAAN LINEAR SATU VARIABEL KELAS VII MTS N 5 MAGELANG
}

\author{
Ika Wahyuni ${ }^{1}$, Novisita Ratu ${ }^{2}$ \\ ${ }^{1}$ Pendidikan Matematika, Universitas Kristen Satya Wacana, 202014@student.uksw.edu \\ 2Pendidikan Matematika, Universitas Kristen Satya Wacana, novisita.ratu@staff.uksw.edu
}

\section{INFO ARTIKEL}

Riwayat Artikel:

Diterima: 28-03-2018

Disetujui: $10-04-2018$

\section{Kata Kunci:}

Kemampuan berpikir kreatif, PLSV

\section{ABSTRAK}

Abstrak: Jenis penelitian ini adalah penelitian kualitatif yang bertujuan untuk mengidentifikasi kemampuan berpikir kreatif matematis siswa dalam menyelesaikan soal Persamaan Linear Satu Variabel kelas VII MTs N 5 Magelang. Subjek penelitian ini adalah 3 orang siswa kelas VII MTs N 5 Magelang yang memiliki kemampuan awal matematika tinggi, sedang, dan rendah. Subjek penelitian ini diambil dengan menggunakan teknik purposive sampling. Teknik pengumpulan data berupa tes tertulis dan wawancara. Berdasarkan hasil analisis dapat disimpulkan bahwa: 1) Subjek dengan kemampuan awal matematika tinggi memiliki kemampuan berpikir kreatif tinggi dimana subjek mampu mencapai aspek keluwesan, fleksibilitas, dan orisinil; 2) Subjek dengan kemampuan awal matematika sedang hanya mampu mencapai aspek keluwesan dan fleksibilitas; 3) Subjek dengan kemampuan awal matematika rendah tidak mampu mencapai aspek keluwesan, fleksibilitas, dan orisinil.

\begin{abstract}
Abstrak: The type of this research s This qualitative research that aims to identify the ability of students' mathematical creative thinking in solving the problem of Linear Equations One Variable class VII MTs N 5 Magelang. The subjects of this research is 3 students of class VII MTs N 5 Magelang who have early high, medium, and low math skills. The subject of this research is taken by using purposive sampling technique. Data collection techniques the form of written tests and interviews. Based on the results of the analysis can be concluded that: 1) Subjects with high early mathematical abilities possess high creative thinking abilities in which subjects are capable of achieving flexibility, flexibility, and original aspects; 2) Subjects with early math skills are only able to attain flexibility and flexibility aspects; 3) Subjects with low initial math skills are unable to achieve flexibility, flexibility, and original aspects.
\end{abstract}

\section{A. LATAR BELAKANG}

Matematika adalah salah satu mata pelajaran yang diperoreh siswa dimulai dari Sekolah Dasar, Sekolah Menengah bahkan sampai perguruan tinggi. Hal ini untuk membekali siswa dalam kemampuan berpikir logis, analitis, sistematis, kritis dan kreaatif serta kemampuan bekerja keras (Depdiknas, 2006). Salah satu pembelajaran matematika adalah untuk membekali siswa dengan kemampuan berpikir kreatif. Aspek kreatif otak dapat membantu menjelaskan konsep-konsep yang abstrak, sehingga memungkinkan siswa untuk mencapai penguasaan yang lebih besar khususnya pada pembelajaran matematika dan sains. Mengajar dengan kreatif dapat mengembangkan kualitas pendidikan, membuat pembelajaran menjadi lebih bermakna (Yusron, 2011 : 130).

Menurut survei PISA ( Programme for Internasional Student Assesment) tahun 2015, Indonesia menempati peringkat ke 63 dari 70 negara yang disurvei dengan skor rata-rata kemampuan matematika siswa Indonesia yaitu 386 , skor tersebut masih dibawah rata-rata internasional (Komendikbud, 2016). Siswa Indonesia menguasai soal yang bersifat rutin, masalah yang sederhana dan pengetahuan akan fakta dalam konteks keseharian. Hal ini berarti tingkat tinggi matematika siswa seperti kemampuan berpikir kreatif masih kurang.

Kurangnya kemampuan berpikir kreatif juga ditunjukkan oleh beberapa peneliti terdahulu yang meneliti tentang kemampuan berpikir kreatif yang mendukung dengan penelitian ini, seperti halnya penelitian yang dilakukan oleh Rahma (2017) menyimpulkan bahwa kemampuan berpikir kreatif diperoleh nilai rata-rata untuk aspek kelancaran mencapai 65,24, untuk aspek fleksibelitas diperoleh nilai rata-rata mencapai 45,83 dan nilai rata-rata aspek elaborasi mencapai 66,67. Dengan demikian dapat disimpulkan bahwa tingkat kemampuan berpikir 
kreatif matematika mahasiswa pada pokok bahasan peluang masih rendah yaitu dengan skor 59,26. Penelitian relevan lain seperti yang dilakukan oleh Laras (2017) menyimpulkan bahwa kemamuan berpikir kreatif pada aspek berpikir lancar siswa termasuk dalam kategori tinggi dengan persentase yang diperoleh sebesar $66,18 \%$, kemampuan berpikir kreatif aspek berpikir luwes siswa termasuk dalam kategori rendah dengan persentase yang diperoleh sebesar 39,71\% dan kemampuan broikir kreatif pada aspek orisinil termasuk dalam kategori rendah dengan persentase yang diperoleh sebesar 20,59\%. Beberapa penelitian tersebut menunjukkan masih banyak siswa yang termasuk dalam kemampuan berpikir kreatif yang rendah. Pada perkembangannya kemampuan berpikir kreatif, kritis, pemecahan masalah dan penalaran matematika dapat mewujudkan kemampuan berpikir tingkat tinggi (Rejendra, 2008). Oleh karena itu kemampuan berpikir kreatif matematika siswa sangat diperlukan oleh siswa.

Berpikir kreatif termasuk dalam kategori berpikir tingkat tinggi. Pohkonen (1997) mendefinisikan berpikir kreatif dalam matematika merupakan kombinasi dari berpikir logis dan berpikir divergen. Berpikir logis digunakan untuk menemukan solusi dalam memecahkan masalah matematika. Sedangkan berpikir divergen mampu menghasilkan banyak gagasan/ide dalam menyelesaikan masalah. Guilford (dalam Munandar, 1999) mengungkapkan bahwa berpikir kreatif sebagai kemampuan untuk melihat bermacam-macam kemungkinan penyelesaian terhadap suatu masalah. Semakin banyak dan beragam kemungkinan penyelesaian masalah yang diberikan seseorang maka semakin kreatiflah orang tersebut, namun tentu saja kemungkinan penyelesaian tersebut haruslah tepat dan benar sesuai permasalahan. Kemampuan berpikir kreatif merupakan hal penting yang perlu dimiliki oleh setiap orang, dengan berpikir kreatif seseorang dapat mewujudkan dirinya melalui berbagai karya, baik berupa gagasan, ide maupun suatu produk (Rahmawati, 2016).

Kemampuan berpikir kreatif matematis merupakan kemampuan yang perlu ada dalam diri siswa untuk menganalisis permasalahan matematika dari berbagai sudut pandang kemudian menyelesaikannya dengan kemampuan banyak solusi dan serta melahirkan ideide kreatif dan banyak gagasan. Kemampuan berpikir disini diantaranya merupakan kemampuan menemukan jawaban yang paling tepat, mampu melihat suatu masalah dari berbagai sudut pandang, dan mampu melahirkan banyak gagasan yang merupakan indikator kelancaran dan keluwesan. Kemampuan berpikir kreatif dapat diukur dengan berbagai kriteria. Menurut Backer dan Shiamda (1998:35) aspek-aspek untuk mengkur kemampuan berpikir kreatif, yitu aspek kelancaran (fluency), aspek keluwesan (flexibility), aspek keaslian (originality).
Aspek kelancaran (fluency) mengacu pada kemampuan siswa dalam memberikan bermacam-macam jawaban, aspek keluwesan (flexibility) mengacu pada kemampuan siswa dalam memberikan alternatif jawaban yang bervariasi/ berbeda, dan aspek keaslian (originality) mengacu pada kemampuan siswa dalam memberikan suatu jawaban yang baru dan unik serta berbeda dari jawaban teman lainnya.

Terdapat dua faktor yang dapat mempengaruhi kemampuan berpikir kreatif yaitu faktor dorongan dari dalam diri individu (internal) dan faktor dorongan dari luar diri individu (eksternal). Munandar (2012) menjelaskan bahwa motivasi instriksik setiap orang untuk mewujudkan potensinya selalu ada, motivasi tersebut hendaknya dibangun sejak dini. Hal ini dapat dilakukan dengan memperkenalkan individu dengan kegitan-kegiatan kreatif, dengan tujuan untuk memunculkan rasa ingin tahu, dan untuk melakukan hal-hal baru. Sedangkan motivasi eksternal individu berasal dari lingkungan maupun mendorong munculnya kreativitas, hendaknya lingkungan sekitar dapat menjadi pendorong bagi individu untuk mampu mengembangkan kreatifitasnya. Penciptaan kondisi keamanan dan kebebasan psikolog memungkinkan timbulnya kemampuan berpikir kreatif seseorang.

Kemampuan berpikir kreatif siswa dapat diketahui dengan pemberian soal terbuka (open-ended). Silver (1997) menyebutkan bahwa pemberian soal terbuka membuat siswa menjadi mempunyi banyak pengalaman dari setiap materi yang telah didapat, siswa mempunyai banyak pengalaman dalam menafsirkan masalah, dan dapat memungkinkan gagasan yang berbeda bila dihubungkan dengan penafsiran yang berbeda pula. Soal terbuka dapat dikatakan sebagai bentuk soal memiliki banyak penyelesaian dengan bermacam versi, artinya bisa dengan cara penyelesaian yang berbeda-beda tergantung kemampuan berpikir kreatif matematis siswa. Aspek keterbukaan dalam pendekatan open ended dapat diklasifikasikan kedalam tiga tipe, yaitu: 1) terbuka proses penyelesaiannya, yaitu soal itu memiliki beberapa cara penyelesaian; 2) terbuka hasilnya, yaitu soal itu memiliki banyak jawaban yang benar; dan 3) terbuka pengembangan lanjutannya, yaitu ketika siswa telah menyelesaikan sesuatu, selanjutnya mereka dapat mengembangkan soal baru berkaitan dengan soal tersebut.

Kelebihan menggunakan permasalahan terbuka menurut Backer dan Shiamda (1998:23) adalah siswa lebih berpartisipasi aktif dalam pembelajaran, siswa mempunyai kesempatan yang lebih untuk menggunakan pengetahuan dan kemampuan matematikanya, siswa dapat menyelesaikan masalah dengan caranya sendiri, siswa termotivasi untuk memberikan bukti. Soal terbuka diterapkan dalam pembelajaran matematika. Ruang lingkup pembelajaran matematika yang diajarkan di SMP 
meliputi aspek-aspek bilangan, geometri, dan pengukuran, aljabar, peluang, dan statistika. Salah satu cabang dalam matematika adalah materi persamaan linear satu variabel yang masuk dalam ilmu alljabar. Materi persamaan linear satu variabel digunakan dalam mendiskripsikan kemampuan berpikir kreatif matematis siswa (Damayanti, 2017). Materi persamaan linear satu variabel pada SMP kelas VII membahas tentang konsep persamaan linear satu variabel, penyelesaian persamaan linear sau variabel. Materi persamaan linear satu variabel mendukung untuk digunakan dalam mengukur kemampuan berpikir kreatif matematis siswa.

Berdasarkan uraian diatas, peneliti ingin mengidentifikasi kemampuan berpikir kreatif matematis siswa pada materi persamaan linear satu variabel kelas VII MTs N 5 Magelang. Penelitian ini diharapkan dapat memberikan identifikasi tentang kemampuan berpikir kreatif matematis siswa sehingga dapat membantu guru maupun sekolah dalam memperbaiki dan merencanakan pembelajaran agar lebih memperhatikan kemampuan berpikir kreatif matematis masing-masing siswa.

\section{B. METODE PENELITIAN}

Jenis penelitian ini adalah deskriptif kualitatif yaitu penelitian yang menggunakan data kualitatif dan dideskripsikan untuk menghasilkan gambaran yang jelas dan terperinci mengenai kemampuan berpikir kreatif matematis siswa pada materi persamaan linear satu variabel. Pendiskripsian kemampuan berpikir kreatif ini berdasarkan tiga komponen kreativitas yang meliputi kelancaran, keluwesan, dan keaslian. Penelitian ini dilakukan di MTs N 5 Magelang. Adapun waktu penelitian ini dilakukan pada tanggal 26 Februari 2018. Subjek dalam penelitian ini adalah siswa MTs N 5 Magelang yang dibagi menjadi siswa yang berkemampuan awal matematika tinggi, sedang, dan rendah.

Penentuan subjek penelitian menggunakan teknik purposive sampling yaitu teknik pengambilan sampel dengan pertimbangan tertentu (Sugiyono, 2012). Subjek penelitian ini adalah siswa kelas VII B yang dipilih berdasarkan rata-rata nilai ulangan harian dan tes tengah semester. Kemudian peneliti dibantu guru matematika memilih 3 siswa yang dikelompokkan menjadi 3 tingkat, yaitu siswa yang berkemampuan awal matemtika tinggi, sedang, dan rendah. Metode yang digunakan dalam penelitian ini adalah metode tes, wawancara, dan dokumentasi. Tes yang dibuat berupa soal terbuka (open-ended) untuk mendiskripsikan kemampuan berpikir kreatif matematis siswa. Metode wawancara digunakan untuk mengetahui kemampuan berpikir kreatif matematis siswa dalam menyelesaikan soal matematika. Dalam penelitian ini, dokumentasi diperoleh dari kegiatan saat penelitian berlangsung terhadap subjek penelitian.

\section{HASIL DAN PEMBAHASAN}

Aspek pencapaian kemampuan berpikir kreatif matematis meliputi fluency, flexibility, dan originaliti. Aspek kelancaran (fluency) mengacu pada kemampuan siswa dalam memberikan bermacam-macam jawaban, aspek keluwesan (flexibility) mengacu pada kemampuan siswa dalam memberikan alternatif jawaban yang bervariasi/ berbeda, dan aspek keaslian (originality) mengacu pada kemampuan siswa dalam memberikan suatu jawaban yang baru dan unik serta berbeda dari jawaban teman lainnya.

Subjek YMR dengan kemampuan awal matematika tinggi seperti yang terlihat dalam Gambar 1, subjek dapat memberikan 5 bentuk persamaan yang berbeda untuk soal 1a dan 8 bentuk persamaan yang berbeda untuk soal $1 \mathrm{~b}$, dimana persamaan-persamaan tersebut setara dengan soal yang diberikan. Hal tersebut menunjukkan bahwa aspek fluency mampu diperlihatkan oleh subjek YMR, dimana subjek tidak hanya memberikan satu atau dua persamaan saja tetapi dengan lancar subjek YMR mampu memberikan beberapa persamaan yang subjek buat dengan nilai yang sama/setara seperti yang ditanyakan dalam soal. Pada proses wawancara subjek YMR dapat dengan lancar menjelaskan jawaban yang diperolehnya. Hal ini serupa dengan penelitian Masruroh (2017) yang menyimpulkan bahwa siswa dengan kemampuan tinggi dapat menuliskan apa yang diketahui yang ada dalam soal dengan tepat, tidak menunjukkan kebingungan dalam memahami soal yang ada, tidak menunjukkan kebingungan dalam menjelaskan apa yang diketahui dan apa yang ditanyakan peneliti, serta menjelaskan yang dimaksud dalam soal dengan kata-kata sendiri.

Subjek YMR dengan kemampuan awal matematika tinggi dapat mencapai aspek flexibility dalam mengerjakan nomor 2. Tercapainya aspek pada permasalahan ini dapat dilihat pada Gambar 2. Subjek YMR juga dengan tepat memberikan jawaban sesuai dengan ketentuan soal yaitu menentukan bilanganbilangan pengganti huruf $r, s, t, u, v$, dan $w$ dengan syarat jumlah bilangan-bilangan pada setiap baris adalah 27. Hal tersebut menunjukkan subjek YMR mampu memperlihatkan fleksibilitas dalam dirinya, dimana subjek YMR mampu memberikan alternatif penyelesaian yang berbeda dengan subjek lainnya. Subjek YMR menentukan nilai-nilia tersebut dengan cara coba-coba, sehingga dapat menentukan nilai dari r, $\mathrm{s}, \mathrm{t}, \mathrm{u}, \mathrm{v}$, dan $\mathrm{w}$ dengan tepat. Ketercapaian aspek flexibility ini terlihat jelas saat dilakukan proses wawancara. Subjek YMR dengan lancar menjelaskan cara memperoleh nilai $\mathrm{r}, \mathrm{s}, \mathrm{t}, \mathrm{u}, \mathrm{v}$, dan w tersebut.

Sebanding dengan penelitian Murni (2013) bahwa pendekatan open ended dapat memberikan kesempatan kepada siswa untuk memperoleh pengalaman, pengetahuan, serta dapat meemcahkan masalah menggunakan berbagia macam cara. Selanjutnya, Fardah (2012) juga menyimpulkan bahwa 
siswa dengan kemampuan berpikir tinggi akan menghasilkan produk berpikir kreatif meliputi bermacam-macam kategori, respon yang dihasilkan berbeda jika dibandingkan dengan siswa yang lain. Hasil yang diberikan cukup rinci dan jelas.

Subjek YMR juga mampu memberikan sesuatu yang baru dari jawaban yang terlihat pada Gambar 3, subjek YMR mampu memberikan kemungkinan jawaban yang tidak dipikirkan oleh subjek lain. Subjek juga mampu manjelaskan cara memperoleh jawaban tersebut dengan tepat. Berdasarkan hal tersebut menunjukkan bahwa indikator aspek originality mampu diperlihatkan oleh subjek YMR dengan mampu memberikan jawaban yang unik dan berbeda dari pada umumya.

Penelitian serupa dilakukan oleh Anggraeny (2015) menyatakan bahwa aspek originality hanya dapat dicapai oleh beberapa siswa. Diantara tiga aspek kemampuan berpikir kreatif, aspek originality lah yang paling rendah dicapai. Pada penelitian ini cukup sulit mendapatkan siswa yang mencapai aspek originality. Hanya siswa dengan kemampuan awal matematika tinggi yang dapat mencapai aspek terseut walaupun belum maksimal. Aspek yang paling mengukur kemampuan berpikir kreatif sebenarnya originality, karena siswa yang mencapai aspek originality pasti mencapai aspek fluency atau flexibility. Hal ini didukung oleh penelitian Akgul (2016) yang menyatakan bahwa hubungan antara aspek originality dengan kemampuan berpikir kreatif sangat erat sehingga apabila siswa sudah dapat mencapai aspek originality dimungkinkan dapat mencapai tingkat berpikir kreatif.

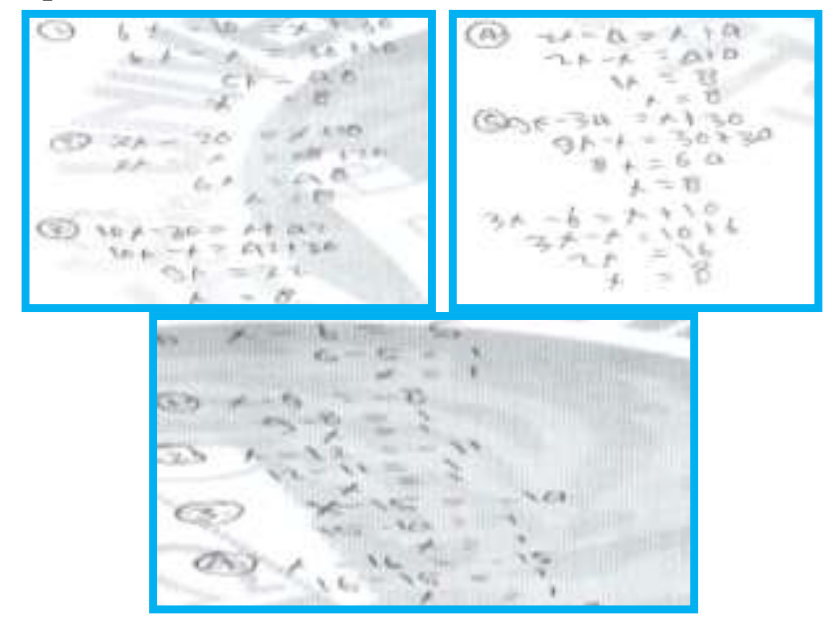

Gambar 1. Jawaban YMR Aspek fluency

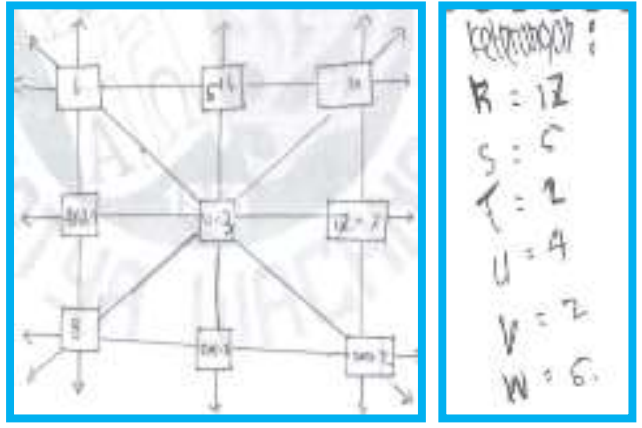

Gambar 2. Jawaban YMR Aspek flexibility
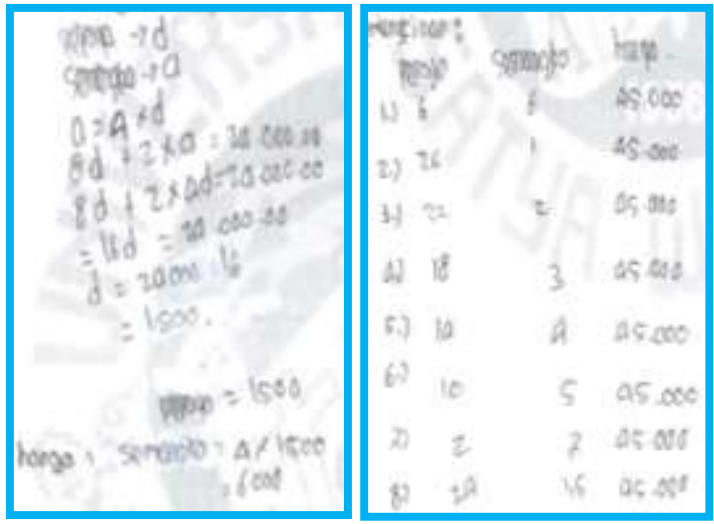

Gambar 3. Jawaban YMR Aspek originality

Subjek LKN dengan kemampuan awal matematika sedang dapat menyelesaiakn soal nomor 1 dengan indikator aspek fluency. Sebagaimana yang terlihat pada Gambar 4, Subjek LKN mampu memberikan jawaban lengkap dimana subjek memberikan 3 persamaan linear satu variabel untuk soal 1a dan 7 persamaan linear satu varial untuk soal $1 \mathrm{~b}$ diaman contoh soal yang diberikan berbeda-beda. Persamaanpersamaan tersebut memiliki nilai yang setara atau ekuivalen dengan persamaan yang diberikan. Hal tersebut menunjukkan bahwa subjek LKN mampu menunjukkan aspek fluency, dimana subjek mampu memberikan beberapa persamaan setara dengan soal yang diberikan.

Subjek LKN juga mampu menunjukkan adanya aspek flexibility dalam dirinya, seperti yang terlihat pada gambar 5, subjek LKN mampu menunjukkan bahwa subjek mampu dengan tepat memberikan jawaban sesuai dengan ketentuan soal, sehingga subjek dapat menentukan bilangan-bilangan yang menggantikan nilai $r, s, t, u, v$, dan $w$ dengan penyelesaian yang tepat dan jelas. Indikator fleksibilitas jelas mampu dimunculkan subjek LKN karena subjek mampu memberikan alternatif lain dalam menentukan nilai $\mathrm{r}, \mathrm{s}, \mathrm{t}, \mathrm{u}, \mathrm{v}$, dan $\mathrm{w}$.

Selanjutnya, subjek LKN dalam mengerjakan soal belum mampu menunjukkan aspek orisinality pada dirinya, karena subjek LKN belum mampu memberikan sesuatu yang unik atau berbeda. Subjek LKN tidak memahami dengan baik informasi-informasi yang terdapat pada soal sehingga informasi tersebut tidak dapat membantu subjek dalam menyelesaikan 
permasalahan yang disajikan dengan lengkap. Hal tersebut berpengaruh terhadap jawaban yang dihasilkan yaitu subjek LKN hanya mampu memberikan jawaban yang terbilang masih umum seperti yang terlihat pada Gambar 6 .

Penelitian ini didukung oleh pendapat yang dikemukakan oleh Mursidik (2015) bahwa untuk kategori sedang pada aspek berpikir lancar baik karena siswa kategori sedang mampu memunculkan satu ide dalam menyelesaikan masalah matematika open-ended sehingga pada aspek berpikir lancar untuk siswa kategori sedang tidak mengalami kesulitan. Kemampuan berpikir kreatif siswa untuk kategori sedang pada aspek berpikir luwes juga berada pada kriteria baik artinya pada umumnya mampu menentukan satu cara dalam menyelesaikan masalah matematika open-ended.

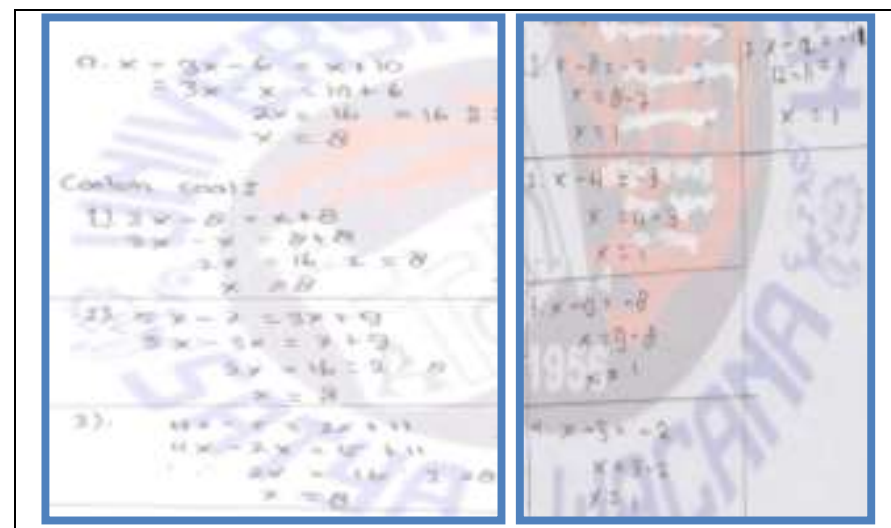

Gambar 4. Jawaban LKN Aspek Fluency

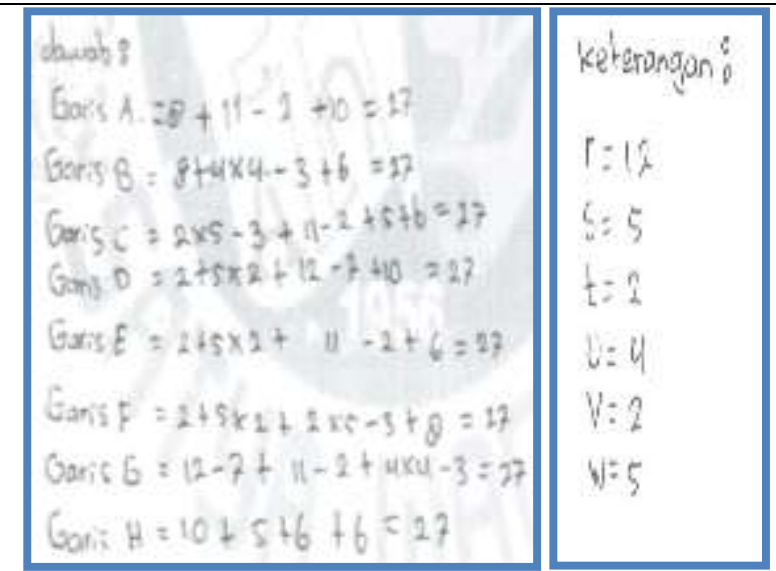

Gambar 5. Jawaban LKN Aspek Flexibility

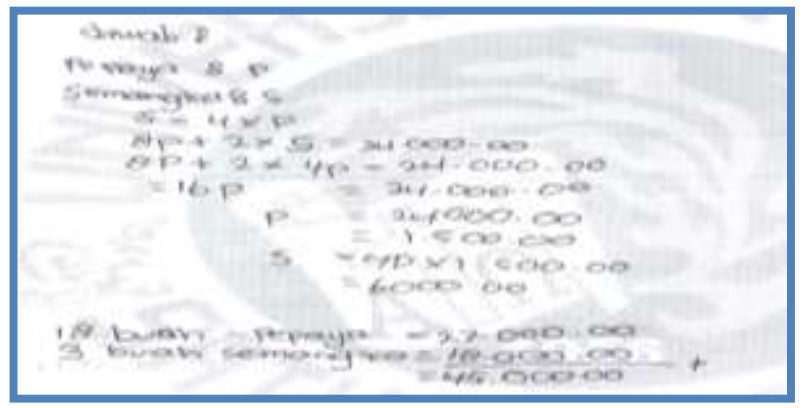

Gambar 6. Jawaban LKN Aspek Originality
Subjek LL dengan kemampuan awal matematika rendah dapat menyelesaikan soal dengan ketiga indikator aspek fluency, flexibility, dan originality. Sebagaimana terlihat pada Gambar 7, subjek LL hanya mampu memberikan satu bentuk persamaan untuk soal nomor 1a dan $1 \mathrm{~b}$. Hal tersebut menunjukkan bahwa subjek LL belum mampu memberikan bermacam-macam jawaban sehingga aspek fluency belum mampu dimunculkan. Subjek LL belum mampu menunjukkan aspek flexibility pada dirinya. Seperti terlihat pada gambar 8, bahwa subjek mampu dengan tepat memberikan jawaban sesuai dengan ketentuan soal, sehingga siswa hanya dapat menentukan nilai r, s, $\mathrm{t}$, dan $\mathrm{v}$ dengan benar, tetapi $\mathrm{u}$ dan w bernilai salah.

Subjek LL juga belum mampu menunjukkan adanya aspek originality dalam dirinya, ini dapat dilihat dari jawaban subjek seperti pada Gambar 9. Subjek LL hanya mampu memberikan satu jawaban yang terbilang masih umum. Subjek LL tidak mampu memberikan kemungkinan-kemungkinan jawaban berbeda atau unik, sehingga menunjukkan bahwa indicator aspek originality belum mampu dimunculkan subjek LL.

Penelitian serupa dilakukan oleh Ahadiyah (2017) bahwa subjek dengan kemampuan matematika rendah belum menunjukkan ketiga indikator berpikir kreatif, sehingga subjek masuk dalam tingkat o (tidak kreatif). Dalam menyelesaikan soal, subjek terpaku pada pekerjaan yang sudah ada, subjek hanya sekedar meniru pola penyelesaian dari buku, dengan tidak memahami lebih mendalam bagaimana cara tersebut diperoleh, sehingga subjek tidak mengembangkan cara penyelesaian yang beragam. Dalam mengerjakan tiap soal subjek membutuhkan waktu yang lama untuk menyelesaikannya. Subjek pada tingkat ini tidak memiliki cara penyelesaian yang berbeda-beda. Selain itu subjek juga tidak menampakkan cara berpikir yang baru dan unik dalam menyelesaikan tiap soal.

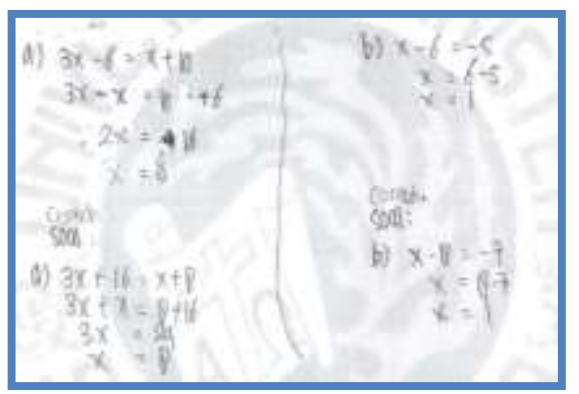

Gambar 7. Jawaban LL Aspek Fluency 


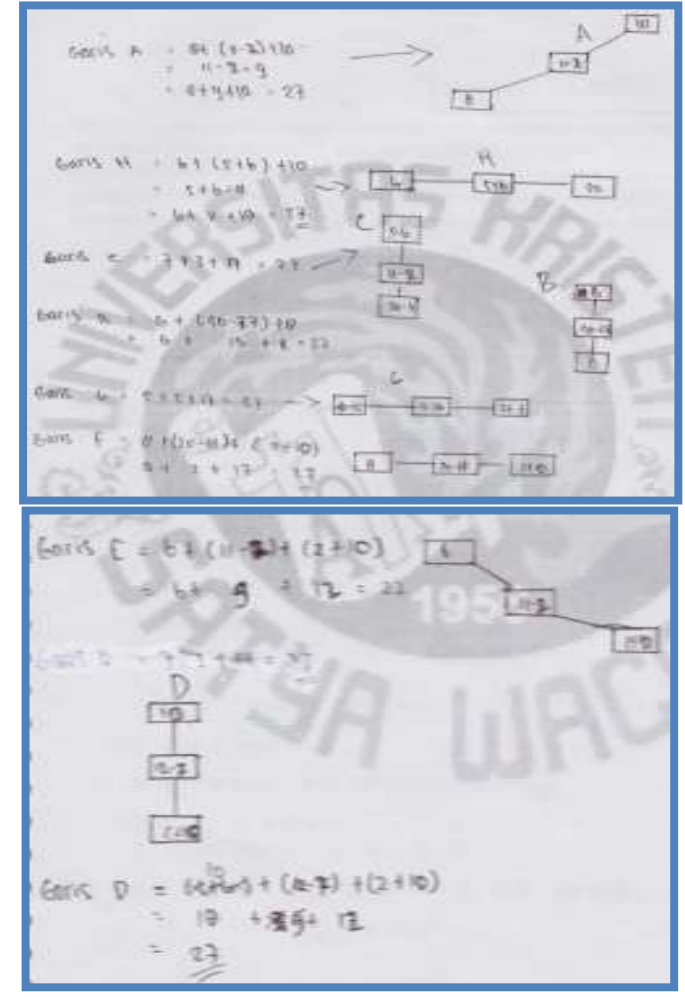

Gambar 8. Jawaban LL Aspek Flexibility
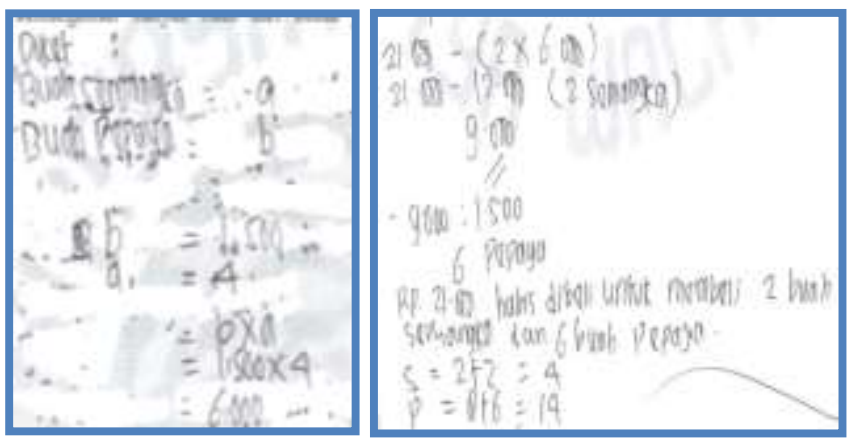

Gambar 9. Jawaban LL Aspek Originality

\section{SIMPULAN DAN SARAN}

Aspek fluency dalam penelitian ini dapat dicapai oleh siswa dengan kemumpuan awal matematika tinggi dan sedang. Siswa dengan kemampuan matematika tinggi dan sedang dapat memberikan beberapa persamaan yang setara atau ekuivalen dengan soal yang diberikan. Tetapi, aspek fluency ini tidak dapat dicapai oleh siswa dengan kemampuan awal matematika rendah. Aspek flexibility dapat dicapai oleh siswa dengan kemampuan matematika tinggi dan sedang . Kedua subjek dengan tepat memberikan jawaban sesuai dengan ketentuan soal dan menggunakan penyelesaian dengan rapi dan jelas . kedua subjek juga mampu memberikan alternatif penyelesaian yang bervariasi dengan lengkap dan jelas, sehingga dapat menentukan bilangan-bilangan untuk menggantikan huruf-huruf tersebut. Sedangkan aspek originality hanya dapat dicapai oleh siswa dengan kemampuan awal matematika tinggi. Siswa dapat mencapai aspek originality dalam menjawab soal nomor 3. Siswa dapat memunculkan ide lain dan unik yang tidak dipikirkan temannya dalam menentukan kemungkinan banyaknya buah-buahan yang dapat dibeli. Subjek dengan kemampuan matematika awal tinggi dapat mencapai ketiga aspek kemampuan berpikir kreatif fluency, flexibility dan originality, sehingga subjek dengan kemampuan awal matematika tinggi mempunyai kemampuan berpikir kreatif tinggi.

Adapun saran bagi peneliti lain, hendaknya penelitian ini dapat dijadikan acuan bagi peneliti selanjutnya agar dapat berkontribusi dalam upaya meningkatkan mutu dan kualitas pendidikan untuk kedepannya. Untuk guru matemaika hendaknya lebih mengembangkan pembelajaran yang dapat meningkatkan kemampuan berpikir kreatif siswa.

\section{UCAPAN TERIMA KASIH}

Peneliti mengucapkan terimakasih kepada dosen pembimbing tugas akhir, guru matematika, dan murid kelas VII MTs N 5 Magelang yang telah membantu dalam menyelesaikan penelitian ini.

\section{DAFTAR PUSTAKA}

[1] Ahadiyah, Fani Latifah (2017). Analisis Kemampuan Berpikir Kreatif Siswa Dalam Menyelesaikan Soal Open Ended Pokok Bahasan Keliling Dan Luas Lingkaran Kelas Viii Smp Negeri 17 Surakarta.

[2] Akgul, S., \& Kahveci, N.G. (2016). A Study On The Development Of Mathematics Creativity Scale. Eurasian Journal Of Educational Research.

[3] Aminulloh, Yusron. (2011). Mindset Pembelajaran. Bandung.Nuansa.

[4] Anggraeny, D.B., Siswono, T.Y. (2013). Identifikasi Tingkat Berpikir Kreatif Siswa Menggunakan Multiple Solution Task (MST). Jurnal Mathedunesa.

[5] Damayanti, Herwinanda Trisnaning. (2017). Kemampuan Berpikir Kreatif Matematis Dalam Menyelesaikan Soal Open Ended Siswa Kelas Vii Smp Batik Surakarta.

[6] Depdiknas. (2006). Peraturan Menteri Pendidikan Nasional. Jakarta: Dirjen.

[7] Fardah, Dini Kinanti. 2012. Analisis Proses Dan Kemampuan Berpikir Kreatif Siswa Dalam Matematika Melalui Tugas Open-Ended. Jurnal Kreano,Semarang: Jurusan Matematika FMIPA UNNES

[8] Faelasofi, Rahma. (2017). Identifikasi Kemampuan Berpikir Kreatif Matematika Pokok Bahasan Peluang. Jurnal Edumath.

[9] Ismara, Laras Dkk. (2017) Kemampuan Berpikir Kreatif Matematis Siswa Dalam Menyelesaikan Soal Open Ended Di Smp. Jurnal Untan

[10] Kemendikbud. (2016). Survei Internasional PISA. Diakses 14 Maret 2018: (Http://Litbang.Kemdikbud.Go.Id/Index.Php/SurveiInternasional-Pisa).

[11] Masruroh, R., Sijado, I., \& Sari, D.R. (2015). Kategori Berpikir Kreatif Siswa Kelas VII SMP Negeri 1 Surakarta Dalam Menyelesaikan Masalah Matematika Pada Materi Pokok Himpunan. Jurnal Elektronik Pembelajaran Matematika. 
[12] Munandar, S. C. U. 1999. Kreativitas \& Keberbakatan: Strategi Mewujudkan Potensi Kreatif \& Bakat. Jakarta: PT Gramedia Pustaka Utama.

[13] Munandar, U. (2012). Pengembangan Kreativitas Anak Berbakat. Jakarta:Rineka Cipta. Murni. (2013). Open Ended Approach In Learning To Improve Student Thinking Skill In Banda Aceh. International Journal Of Independent Research And Studies.

[14] Mursidik, E.M., Samsiyah, N., Rudyanto, H.E. (2015). Kemampuan Berpikir Kreatif Dalam Memecahkan Masalah Matematika Open-Ended Ditinjau Dari Tingkat Kemampuan Matematika Pada Siswa Sekolah Dasar. Journal Pedagogia.

[15] Putri, V.S.R., \& Wijayanti, P. (2013). Identifikasi Tingkat Kemampuan Berpikir Kreatif (TKBK) Siswa Dalam Menyelesaikan Soal Open Ended Pada Materi Segiempat Di Kelas VIII SMP.Jurnal Mathedunesa.

[16] Rahmawati, Irma. ( 2016). Analisis Kemampuan Brpikir Kreatif Matematis Siswa Smp. Universitas Pendidikan Islam Negeri Syarif Hidayatullah.

[17] Rajendra. (2008). Teaching And Acquiring Higher Order Thinking Skills Theory And Practice. Tanjong Malim: Universiti Pendidikan Sultan Idris

[18] Shimada, Shigeru \& Jerry P. Becker. 1998. The OpenEnded Approach: A New Proposal For Teaching Mathematics. Virginia: National Council Of Teachers Of Mathematics.

[19] Silver. (1997). International Reviews On Mathematical Education. Fostering Creativity Through Intruction Rich In Mathematical Problem Solving And Problem Posing.

[20] Sugiyono. 2012. Metode Penelitian Pendidikan Pendekatan Kuantitatif, Kualitatif, Dan R\&D. Bandung: Alfabeta. 